\title{
0 kulturalizm heterogeniczności kulturowej. Ku antropologicznej klasyfikacji cudzoziemców w Poznaniu
}

\section{Abstract \\ For the Culturalism of Cultural Heterogeneity: Towards the Anthropological Classification of Foreigners in Poznań}

This article discusses the premises and outcomes of the ethnographic project "Foreigners in Poznań: Cultural Heterogeneity in Big Cities on the Example of Poznań", by asking about the place of ethnicity (fundamental for anthropological studies) in the research of cultural heterogeneity. The independent qualitative analysis of empirical material demonstrates that even if generally ethnic identities do not determine directly the identifications of foreigners in Poznań, then the pan- or interethnic identities are a key to understanding how immigrants organise themselves or are organised in groups or categories. An account of cultural heterogeneity through the prism of cultural identities offers a purely anthropological alternative or at least an addendum to socio-economic classification of foreigners implemented within this project.

Keywords: cultural heterogeneity, cultural identity, ethnicity, immigrants, city

Na płaszczyźnie studiów migracyjnych coraz częściej nawołuje się do zdjęcia „etnicznych okularów” (Glick Schiller, Çağlar, Guldbrandsen 2006) i „odetnicznienia projektów badawczych poprzez obranie nieetnicznych jednostek obserwacji, aby [móc] zobaczyć zarówno pojawienie się bliskości etnicznej, jak i jej brak lub zanik" (Wimmer 2009: 262). Poznańskim cudzoziemcom poświęcono wiele opracowań (Bloch, Goździak 2010; Buchowski, Schmidt 2012a; Bloch, Main, Sydow 2015; 
Czerniejewska 2016; Sydow 2017), w których starano się realizować powyższe zalecenia, obserwując imigrantów spoza Unii Europejskiej, pacjentów, imigrantów „Z miłości” i wolontariuszy, wyznania o charakterze misyjnym, sektory biznesu, edukacji oraz handlu i usług, a także rynek pracy. Niestety, procesom (de)mobilizacji etnicznej, kwestii narodowości czy tożsamości kulturowej nie poświęcono większej uwagi. Nawet w opracowaniu dotyczącym „heterogeniczności kulturowej" ponad aspektami kulturowymi znaczenie nadrzędne mają struktury społeczne (Buchowski, Schmidt 2012b: 19; wyróżnienie oryginalne), co zresztą ujawnia się w nacechowanej socjologicznie i ekonomicznie klasyfikacji imigrantów (Chwieduk, Schmidt 2012) ${ }^{1}$.

Chociaż jestem świadomy słabości kulturalizmu, a w szczególności ograniczeń, jakie niesie za sobą uznawanie etniczności za centralną zasadę społecznej organizacji, to niedocenienie kultury lub etniczności wraz z nadmierną koncentracją na „sektorach” i „instytucjach” prowadzi do przesocjologizowania różnic między ludźmi². Jeśli zatem Fredrik Barth $(1983,1984)$ był zmuszony nawoływać, by w analizach pluralizmu kulturowego uwzględniać obok etniczności inne społecznie znaczące wymiary, takie jak religia, zawód, płeć, a nawet stopień wolności osobistej (niewolnicy) czy miejskości, to obecna sytuacja nakazuje mi przypomnieć, że etniczność, narodowość czy, szerzej, tożsamość kulturowa, jest równie(ż) ważnym aspektem heterogeniczności kulturowej.

W ramach niniejszego artykułu chciałbym dopełnić obrazu heterogeniczności kulturowej w Poznaniu, przedstawiając wyniki niezależnej analizy wewnętrznych i zewnętrznych aktów identyfikacji cudzoziemców czy też kulturowych sposobów organizowania się/ich w grupy/kategorie (Barth 1969, 2004, Ardener 2018: rozdz. 3,7, 1992) czy klasy (Bourdieu 2005) ${ }^{3}$. Materiału empirycznego dla tej stric-

1 Socjologiczność ujawnia się w apriorycznym, statycznym i porządkującym charakterze klasyfikacji, a także w nacisku położonym na instytucje. Z kolei ekonomiczność ujawnia się wprost w pojęciu „sektorów” biznesu, handlu i usług oraz edukacji, a pośrednio w kategoriach studentów oraz imigrantów „z miłości” i wolontariuszy, którzy utrzymują się zasadniczo ze stypendiów (studenci) lub też pozostają na utrzymaniu partnera, jeśli nie pracują w innych sektorach („imigranci z miłości”) czy też świadczą pracę nieodpłatną (wolontariusze). O ile etniczność/narodowość stanowi istotny aspekt przypadków studentów tajwańskich (Stanisz 2012) i białoruskich (Pakieła 2012), o tyle koncentracja na statusie studenta nie pozwoliła na pełne omówienie zagadnienia etniczności. Paradoksalnie kwestia etniczności została omówiona najpełniej w przypadku „trudno dostępnych” Romów/Cyganów rumuńskich (Chwieduk 2012).

2 Warto odnotować, że o ile Buchowski (wraz z zespołem) wpadł w tę pułapkę przy okazji studiów migracyjnych, o tyle uniknął jej na gruncie badań neoliberalnego postsocjalizmu (Buchowski 2017).

3 Perspektywę teoretyczną artykułu funduje antropologiczna koncepcja etniczności Bartha, która przez pół wieku nie straciła w ogóle na wartości (Vermeulen, Govers 1994; Eriksen, Jakoubek 2019; por. Eriksen 2013). Ustalenia Edwina Ardenera należy traktować jako poszerzające (Banks 1996: rozdz. 5). 
te antropologicznej klasyfikacji ${ }^{4}$, dostarczyły mi 263 noty dotyczące obywateli 58 państw (w tym Tajwanu) - pozyskane przez zespół ponad 20 badaczy realizujących w latach 2009-2012 projekt „Cudzoziemcy w Polsce. Heterogeniczność kulturowa ośrodków wielkomiejskich na przykładzie Poznania" i zanalizowane we wspomnianym już opracowaniu Buchowskiego i Schmidta (2012a) ${ }^{5}$. Praca ta z oczywistych powodów stanowi bezpośredni punkt odniesienia dla przeprowadzonej analizy i zastosowanego tu klucza klasyfikacji cudzoziemców.

Mimo że etniczność czy narodowość w analizie antropologicznej (etnologicznej) stanowi podstawową jednostkę obserwacji, to w optyce rzeczonego projektu pozycję tę zajmuje obywatelstwo - bliższe studiom socjologicznym, historycznym czy politologicznym ${ }^{6}$. Być może dla większości cudzoziemców różnica między obywatelstwem a narodowością nie ma większego znaczenia, lecz od tej reguły istnieją ważne wyjątki. Dla cudzoziemców o polskich korzeniach etniczność wydaje się ważniejsza od obywatelstwa, gdyż to ona stanowi zasadniczy motyw ich obecności w Polsce, $z$ kolei stygmatyzowani ze względu na swoje wyznanie Turcy bułgarscy niezbyt chętnie przyznają się do swojej etniczności. Jednocześnie widoczny jest brak konsekwencji ze strony badaczy, którzy wyodrębniają pewne grupy po linii narodowości: Romów/Cyganów rumuńskich albo Tajwańczyków, których większość legitymuje się obywatelstwem amerykańskim lub kanadyjskim. Badacze nie zawsze wykazują się też odpowiednimi kompetencjami, powołując do życia: narodowość „Indie”, pochodzenie „Brytyjczyk” i obywatelstwo "angielskie" albo też (najprawdopodobniej) w gronie Belgów nie dostrzegając Flamandów i jednej Walonki itp.

Zignorowanie kwestii rasy nie pozwala na uzyskanie odpowiedzi na najbardziej podstawowe społecznie pytanie - o wygląd/ciało (zob. Harrison 1995). Na znaczenie analityczne tej kategorii (nie tylko opisowe) wskazuje choćby przypadek informatora narodowości „RPA”, jako że w Republice Południowej Afryki rasa stanowi podstawę identyfikacji. Ponadto mniej lub bardziej wyobrażona od-

4 Przywołuję tutaj znaczenie właściwe nie metodologii nauk, ale naukom społecznym (Ellen 2008).

Za metodologię projektu, interpretacje kategorii imigrantów i studia przypadków, a także noty odpowiadają imiennie ich autorzy. W tym zakresie moje działanie ograniczyło się do sporządzenia dwóch not. O ile odpowiedzialność za niniejszą próbę poszerzenia obrazu heterogeniczności kulturowej spada całkowicie na mnie, o tyle, podkreślam, nie mam wpływu na wartość informacyjną zastanych materiałów empirycznych, które poddaję analizie. Zarówno dogłębna analiza tożsamości poszczególnych grup (na przykład Romów), jak i wyczerpująca analiza heterogeniczności kulturowej Poznania zdecydowanie wykracza poza ramy tego artykułu. Z uwagi na wymogi formalne jestem zmuszony dokonać możliwie krótkiej charakterystyki grup cudzoziemców, co bezsprzecznie odbija się niekorzystnie na stylistyce centralnej części artykułu. Pozbycie się wszelkich odniesień do konkretnych not ma skutek przeciwny, ale to z kolei negatywnie wpływa na stronę merytoryczną artykułu. Ufam, że te wymuszone słabości tekstu nie przesłonią jego zalet.

6 Obywatelstwo wraz z kategoryzacją imigrantów stanowi podstawę systemu kodowania not. 
mienność rasowa stanowi od dawna znaczący aspekt polskich obrazów obcych (Nawrocki 1990).

Analiza wywiadów ujawnia, że dla cudzoziemców zamieszkujących w Poznaniu narodowość względnie rzadko stanowi najważniejszy aspekt tożsamości. Niektórzy respondenci wyrażają wprost brak potrzeby solidarności etnicznej, utrzymując kontakty przede wszystkim z Polakami. Z kolei liderzy organizacji o profilu etnicznym mówią o niechęci do zrzeszania się w ich ramach, a także o zindywidualizowaniu kontaktów między cudzoziemcami jednej narodowości. Wydaje się, że dla uchwycenia heterogeniczności kulturowej w Poznaniu największe znaczenie mają - co postaram się wykazać - solidarności pan- lub interetniczne: motywowane czynnikami językowymi, religijnymi, geopolitycznymi lub zawodowymi, częstokroć wzmacniane poprzez instytucje o profilu kulturalnym, religijnym, zawodowym, a nawet płciowym. Pewne segmenty pan-/interetniczne utrzymują ze sobą jakiegoś rodzaju kontakty, a w każdym razie istnieje między nimi jakiegoś rodzaju wspólnota kultury i tożsamości, która ustanawia wyższego rzędu bloki geopolityczne wykazujące daleko posunięte podobieństwo do zimnowojennego podziału na Pierwszy, Drugi i Trzeci Świat. Różne poziomy identyfikacji strukturyzują centralną część artykułu.

Porządkując zróżnicowanie kulturowe cudzoziemców za pomocą kategorii pan-/interetnicznych, kieruję się nie tyle wskazaniami inicjującymi niniejszy artykuł, ile materiałem empirycznym, który zmusza do przyjęcia takiej perspektywy sytuacyjnej (Moerman 1965; Nagata 1974; Okamura 1981). Kilkupoziomowa klasyfikacja tożsamości nie oznacza jednak, że rezygnuję z próby uchwycenia etniczności jako takiej, jest bowiem wprost przeciwnie: tam, gdzie jest to etnograficznie możliwe, staram się wykazać pewną niezależność „subiektywnie” pojmowanej narodowości od nieco bardziej „obiektywnego” obywatelstwa, a przede wszystkim ukazać etniczność jako uwikłaną czy przecinającą się z innymi kategoriami identyfikacyjnymi (Eriksen 2013, por. też Filip 2012).

\section{„Wschód"}

Cudzoziemcy ze „Wschodu” identyfikują się przede wszystkim w kontraście z „Zachodem”, czyli krajami zachodniej i północnej Europy oraz Ameryki Północnej i - umniejszając tu różnice geopolityczne - Południowej. Blok „Wschodni” cechuje doświadczenie socjalizmu, dominacja języków słowiańskich ze szczególnym uwzględnieniem języka rosyjskiego dość często pełniącego funkcję lingua franca oraz znaczenie religii chrześcijańskich: rzymskiego i greckiego katolicyzmu oraz prawosławia. Mimo że blok „Wschodni” tworzą zasadniczo kraje Europy Wschodniej, kategoria ta wykracza poza granice kontynentu, obejmując kilka byłych republik radzieckich znajdujących się na obszarze Azji. W obrębie bloku „Wschodniego" wyróżnić należy dwa segmenty interetniczne. 
Segment „Ruski” obejmuje cudzoziemców pochodzących z terenów dawnego Związku Radzieckiego, identyfikowanych jako „Ruscy”, dla których płaszczyznę komunikacji stanowi język rosyjski. W obrębie segmentu da się wyróżnić dwa podsegmenty, z linią podziału przebiegającą nie tylko po linii profesji i wieku oraz pochodzenia, ale także narodowości.

Podsegment „Ruscy-Studenci” tworzą cudzoziemcy młodsi wiekiem (osoby starsze są tu $\mathrm{w}$ zdecydowanej mniejszości), zwykle polskiego pochodzenia, w związku z czym wielu z nich jeszcze przed przyjazdem do Polski na studia znało język polski na poziomie co najmniej komunikatywnym. Solidarność pan-, czy właściwie interetniczna, jest tworzona przede wszystkim poprzez działalność organizacji studenckiej Wspólnota Polska i jej przybudówek (Pakieła, Przepiera 2012), pomagających obcokrajowcom mającym polskie korzenie odnaleźć się w nowej rzeczywistości. Mimo że Wspólnota Polska ma w swoim statusie zapis o szerzeniu polskiej kultury, w praktyce działalność organizacji nie wykracza poza aktywność integracyjną i zabawową (tzw. imprezy radzieckie). Największą obojętność wobec działalności WP wykazują Rosjanie, którzy rzadko legitymują się polskim pochodzeniem, oraz Białorusini, którzy z powodów politycznych kontestują prorosyjski profil WP.

Cudzoziemcy polskiego pochodzenia identyfikują się mocno z polskością, chociaż są często świadomi konstruowanego charakteru swojej narodowości, będącej w dużej mierze wynikiem „etnicyzacji religii” w kraju wysyłającym (w byłych republikach radzieckich katolików kategoryzuje się społecznie jako Polaków). Tylko pojedyncze osoby polskiego pochodzenia nie identyfikują się jako Polacy, czego szczególnie wyrazistym przykładem jest Białorusinka, która czyni tak, mimo że nie zna języka białoruskiego, lecz tylko rosyjski i polski.

Cudzoziemcy ze „Wschodu” zwracają uwagę na względną obcość Polski, przy czym chodzi nie tyle o kwestie geograficzne, ile społeczne, gospodarcze i polityczne. Taka percepcja Polski była wyrażana przez respondentów określaniem Polski jako „Zachodu”, przy równoczesnej afirmacji „Wschodniej” tożsamości.

Ukraińcy (24 osoby): przewaga kobiet, zwykle osoby w wieku 19-29 lat, ale kilka osób starszych (36-45 lat). W pierwszej grupie zdecydowana większość to studenci lub rzadziej absolwenci. Niemal wszyscy przyjechali do Polski na studia (w tym doktoranckie), pojedyncze osoby uczyły się w Polsce już w liceum, a nawet gimnazjum. Dominują szeroko pojęte kierunki humanistyczne, przede wszystkim filologie (zwłaszcza rosyjsko-ukraińska i ukraińsko-białoruska), ale też wschodoznawstwo, stosunki międzynarodowe i historia. Wśród czterech osób niestudiujących, tylko jedna jest bezrobotna i uczestniczy w programie realizowanym przez Centrum Integracji Społecznej „Barka”. W tej grupie wiekowej aż czterech cudzoziemców trafiło do Polski w ramach wolontariatu w Stowarzyszeniu „Jeden Świat" (tylko jedna z osób ma pochodzenie polskie), dzięki czemu połowa z nich podjęła tu studia. 
W drugiej grupie wiekowej dominują osoby mające wykształcenie wyższe (farmacja, rzeźba, geodezja, doktorat z muzykologii), ale tylko połowa z nich ukończyła studia w Polsce; osoby te wykonują pracę zgodną ze swoimi kwalifikacjami. Poza tym dwie kobiety trudnią się handlem na poznańskich rynkach (zob. podsegment „Ruscy-Handlarze”). Głównym motywem pobytu w Polsce jest możliwość zarobku; tylko jedna osoba przyjechała do męża.

Zaledwie połowa cudzoziemców z Ukrainy jest pochodzenia ukraińskiego (w tym przypadek korzeni ukraińsko-afrykańskich), pozostali legitymują się pochodzeniem polskim. Mimo świadomości polskiego pochodzenia wielu z nich czuje się (bardziej) Ukraińcami, co dotyczy także osób, których rodzina (rodzice) jest wyznania katolickiego oraz dobrze zna język i kulturę polską, a sami respondenci otrzymali w tym kierunku edukację. Większość cudzoziemców pochodzenia polskiego wyznaje rzymski katolicyzm (pojedyncze przypadki prawosławia i grekokatolicyzmu). Z kolei wśród cudzoziemców ukraińskiego pochodzenia dominującymi wyznaniami są grekokatolicyzm i prawosławie (tylko jeden przypadek wyznania rzymskokatolickiego, co wyraźnie wpłynęło na biografię respondentki, która podjęła naukę w liceum u sióstr Urszulanek).

W większości przypadków cudzoziemcy pozostają w związkach z Polakami, rzadziej w związkach z Ukraińcami: na odległość lub na miejscu. W jednym przypadku odnotowano związek Ukrainki z Indusem.

Białorusini (21 osób): grupa płciowo mieszana, w zdecydowanej większości studenci w wieku 19-27 lat, rzadziej absolwenci w wieku 34-36 lat (jeden przypadek ukończenia studiów na Białorusi, obecnie na stażu w Polsce); tylko osoba najstarsza wiekiem ukończyła technikum. Białorusini zwykle zawierają związki z osobami narodowości białoruskiej lub polskiej, zdecydowanie rzadziej narodowości ukraińskiej lub innej (greckiej).

Ponad połowa respondentów legitymuje się polskim pochodzeniem. Przeważają wśród nich katolicy, raczej niepraktykujący; pojedyncze osoby są wyznania prawosławnego. Większość przyjechała na studia do Polski, korzystając z programu RP skierowanego do Białorusinów polskiego pochodzenia, tylko nieliczni nie skorzystali z polskiego pochodzenia. Dominują kierunki społeczne i humanistyczne: stosunki międzynarodowe (również w ramach MISH z politologią i wschodoznawstwem), socjologia, turystyka, dziennikarstwo i komunikacja społeczna, filmoznawstwo, ale zdarzają się także kierunki artystyczne.

Białorusi niemający polskiego pochodzenia są zwykle wyznania prawosławnego (niepraktykujący), z wyjątkiem jednego katolika. Większość przyjechała do Poznania, by kontynuować naukę w ramach stypendium Kalinowskiego ze względu na wyrzucenie ich z uczelni za działalność opozycyjną (Pakieła 2012), ale dzięki niemu w Poznaniu studiują także dwie osoby pochodzenia polskiego. $\mathrm{Z}$ reguły studiowanymi kierunkami są stosunki międzynarodowe i politologia, rzadziej historia lub muzykologia. Osoby te często mają nastawienie antyrosyjskie i z podejrzliwością odnoszą się do działań Wspólnoty Polskiej. Białorusini, którzy 
przybyli do Polski na studia, nie korzystając ze stypendium Kalinowskiego, studiują filologie na Uniwersytecie im. Adama Mickiewicza (angielską lub rosyjską) lub ekonomię w Wyższej Szkole Bankowej.

Rosjanki (9 osób): same kobiety, prawie zawsze w wieku poniżej 31 lat. Wykształcenie wyższe, $\mathrm{z}$ reguły studia ukończone w Rosji, rzadziej przyjazd na studia do Polski. Zwykle w związkach z Polakami (w tym związek z żonatym mężczyzną oraz przypadek rozwodu), pojedynczy przypadek związku z Anglikiem. Dominuje narodowość rosyjska, są jednak trzy przypadki pochodzenia polskiego i jeden pochodzenia żydowsko-niemieckiego. Uwagę zwraca politycznie kształtowany ateizm: spośród czterech przypadków chrztu (częściowo tajnego) w cerkwi, tylko jedna kobieta praktykuje prawosławie, a inna (55 lat) skłania się ku buddyzmowi; dwie inne kobiety wychowano $\mathrm{w}$ ateizmie, ale jedna $\mathrm{z}$ nich przyjęła pod wpływem męża wiarę katolicką. Życie zawodowe związane z filologią: lektorki języka rosyjskiego, tłumaczki lub kontakty firmowe ze „Wschodem”.

Narodowość rosyjską wskazuje także kobieta sklasyfikowana po linii obywatelstwa jako Uzbeczka: 21 lat, studentka, pochodzenie polskie, prawosławna niepraktykująca. W Polsce mieszka jej kuzynka (Poznań) i siostra (Wrocław). W związku z Bułgarem, kontakty towarzyskie z grupą rosyjskojęzyczną.

Kazachowie (4 osoby): grupa z przewagą kobiet, zwykle studentek, oraz mężczyzna, lat 31, biznesman. Wszyscy cudzoziemcy przybyli z Kazachstanu są pochodzenia polskiego, a jednocześnie wyznania katolickiego, choć niekoniecznie praktykujący. Nie licząc jednej studentki, respondenci nie zamierzają wracać do Kazachstanu.

Litwini (4 osoby): grupa z przewagą kobiet, w większości osoby studiujące, w wieku 22-23 lat. Jedyna starsza osoba (45 lat) handluje na placu Wielkopolskim, pobyt w Polsce wahadłowy. Niepełne dane na temat wyznania, połowa to katolicy, z czego tylko osoba starsza jest praktykująca. Wszyscy są pochodzenia polskiego.

Lotyszka: 34 lata, pochodzenie polskie, niepraktykująca katoliczka, zamężna z Katalończykiem, lektorka zatrudniona na UAM.

Na pograniczu tego podsegmentu funkcjonują Bułgarki ( 2 osoby): łączy je wyznanie prawosławne, dobra znajomość polskiego i pozostawanie w związkach z Polakami; różni je natomiast wiek, wykształcenie i zawód. Starsza (52 lata) ma wykształcenie podstawowe i pracuje jako gospodyni domowa. Młodsza (28 lat), prawdopodobnie polskiego pochodzenia, jest doktorantką na filologii polskiej UAM, w czasie studiów była opiekunką studentów z programu Erasmus i członkinią koła naukowego „Europa Środkowa”.

Podsegment „Ruscy-Handlarze” wydaje się w najwyższym stopniu ucieleśniać stereotyp „Ruskiego”, stanowiąc ilustrację uzawodowienia etniczności. Tworzą go cudzoziemcy w wieku zwykle powyżej 30, a nierzadko 40 lat. W tym podsegmencie i w przypadku pozostałych segmentów oraz bloków w ogóle, pochodzenie 
polskie jest niemal niespotykane. Granice podsegmentu poszerzają pojedynczy przedstawiciele innych narodowości, zwłaszcza dwie Ukrainki i Litwinka (zob. wyżej), ale także jeden Rumun (nieznający języka rosyjskiego, zob. niżej). Poza granicami podsegmentu znajduje się jeden Chińczyk (szerzej na temat handlarzy: Rydzewski 2012).

Ormianie (6 osób): grupa wyraźnie zmaskulinizowana (tylko jedna kobieta), zwykle w wieku 44-45 lat, w pojedynczych przypadkach młodsi (34 lata) lub starsi (60 lat). Ormianie stanowią przykład zasiedziałych cudzoziemców mieszkających w Polsce od kilkunastu (14-22) lat, którzy stosunkowo mocno ulegli polonizacji; pozostają w związkach małżeńskich z przedstawicielami narodowości polskiej. Tylko jeden Ormianin ma polskie pochodzenie i jednocześnie białoruskie obywatelstwo, w Polsce przebywa od niedawna. Zdecydowana większość Ormian pracuje fizycznie, $\mathrm{z}$ reguły handlując na targowisku, a jeden jako kucharz z kebabiarni. Reguła ta dotyczy to także osób z wyższym wykształceniem, nie licząc lektora języka rosyjskiego pracującego na UAM. O pewnej specyfice Ormian stanowi wyznanie, jako że z reguły należą oni do Apostolskiego Kościoła Ormiańskiego, chociaż raczej nie są praktykujący. Wśród respondentów odnotowano jednak pojedyncze przypadki: wyznania prawosławnego, „chrześcijanina” nieuczęszczającego do kościoła, a Ormianin polskiego pochodzenia jest niepraktykującym katolikiem. Grupa ma rozwinięte kontakty transnarodowe.

Gruzini ( 2 osoby): diada informatorów pod względem płci mieszana i w różnym wieku, ale z zebranych informacji wynika, że jest to grupa raczej zmaskulinizowana, w związkach z Polkami. Gruzini spotykają się w cerkwi, są prawosławni. Starszy respondent to mężczyzna zasiedziały w Polsce, spolonizowany, sprzedawca na rynku przy ul. Bukowskiej (wykształcenie wyższe, ekonomia), jego żona jest Gruzinką, a zatem w przeciwieństwie do większości miejscowych Gruzinów nie ma krewnych Polaków. Na tym tle wyjątkiem jest młodsza respondentka, która studiuje w Polsce i przebywa tu od półtora roku.

Na pograniczu podsegmentu lokują się Turcy bułgarscy (3 osoby), samoidentyfikujący się jako „Bułgarzy” (obywatelstwo bułgarskie), zidentyfikowani ostatecznie jako Pomacy (Rydzewski 2012: 102). Grupa płciowo mieszana, parająca się z reguły handlem, wyróżnia się wyznaniem muzułmańskim i językiem tureckim. Z pozyskanych informacji wynika, że Pomaków w Poznaniu mieszka około 100.

Segment „stowiański” zrzesza cudzoziemców mówiących językami słowiańskimi grupy zachodniej i południowej. O solidarności panetnicznej stanowi tu wspólnota zawodowa, ponieważ cudzoziemcy w większości pracują jako lektorzy w dawnym ${ }^{7}$ Instytucie Filologii Słowiańskiej UAM. Mimo to segment tworzą też dwie pomniejsze jednostki charakterze pan- lub interetnicznym.

\footnotetext{
Przed reformą szkolnictwa wyższego i nauki w 2019 roku.
} 
Podsegment jugosłowiański zrzesza mieszkańców byłej Jugosławii, wyznających zwykle prawosławie. Dla połowy respondentów ważną komponentą tożsamości jest przynależność do mniejszości seksualnych; Polska jest przez nich traktowana jako azyl z powodu dyskryminacji w swoim kraju. Osoby bardzo dobrze mówiące po polsku; rozpiętość wieku 29-43 lat.

Serbowie ( 2 osoby): obu płci, pozostający w związkach z Polkami (kobieta jest orientacji homoseksualnej). Wiek: 31 i 43 lata. Wyznanie prawosławne, niepraktykujący. Prawdopodobnie jeszcze jacyś Serbowie (więcej niż dwoje) pracują jako lektorzy na UAM; konkretna liczba ani płeć nie są znane. Spotykają się często na kawie.

Chorwat: około 40 lat, kawaler, ateista, orientacja prawdopodobnie homoseksualna. Wykształcenie wyższe z doktoratem, pracuje jako lektor na UAM, mieszka w Polsce od 13 lat. Obywatelstwo bośniackie i chorwackie.

Macedończyk: 29 lat, kawaler, wykształcenie wyższe, lektor na UAM. Wyznanie prawosławne.

Podsegment wyszehradzki tworzą cudzoziemcy z krajów Grupy Wyszehradzkiej, zazwyczaj wyznania katolickiego, rzadziej protestanci, często w związkach z Polakami. Dominującą pozycję zajmują Czesi. W podsegment ten został włączony Węgier - ze względów geopolitycznych i z racji małżeństwa z Czeszką, niemożliwe jest jednak stwierdzenie, czy jest to wyraz jakiejś szerszej tendencji w ramach tego podsegmentu.

Czesi (4 osoby): brak wyraźnego profilu płciowego, rozpiętość wieku 31-52 lat. W Polsce zwykle mieszkają przynajmniej od 10 lat. Według pozyskanych informacji w Poznaniu mieszka 14 Czechów. Z reguły katolicy, jeden przypadek ewangelika praktykującego „okazjonalnie”. Czesi są zintegrowani z Polakami (część z nich pozostaje lub pozostawała w związkach z Polkami), nie wykazują tendencji do solidarności etnicznej, mają jednak poczucie własnej odmienności (jeden przypadek pochodzenia polskiego). Poza kuchnią głównym wyznacznikiem odrębności Czechów jest liberalizm światopoglądowy. Wszystkie osoby, z którymi przeprowadzono wywiad pracują na UAM, z reguły jako lektorzy, w jednym przypadku jako pedagog. Ze względu na relacje zawodowe utrzymują stosunkowo bliskie kontakty $\mathrm{z}$ blokiem jugosłowiańskim.

Słowaczka: 60 lat, mąż Polak, katoliczka. Pracownica biblioteki.

Węgier: 37 lat, żonaty z Czeszką, kalwinista. Wykształcenie wyższe, pracownik UAM.

Kilka grup trudno zaklasyfikować do któregokolwiek segmentu bloku "Wschodniego" (na podstawie zebranego materiału empirycznego):

Rumuni (3 osoby): informatorzy w wieku średnim, bez wyraźnego profilu płciowego i zawodowego (lektor, drobny handlarz, biznesmen). Zwykle zasiedziali w Polsce (co najmniej 17 lat), w związkach małżeńskich z przedstawicielami narodowości polskiej, legitymujący się podwójnym obywatelstwem, wyznania ka- 
tolickiego, choć niekoniecznie praktykujący. W jednym przypadku do czynienia mamy z prawosławnym biznesmenem, który z rodziną przyjechał do Poznania w celach zawodowych. Najwłaściwsze wydaje się pozycjonowanie ich pomiędzy segmentem „ruskim” a mikrosegmentem „jugosłowiańskim”.

Dwie kolejne grupy wyróżniają się, niezależnie od siebie, silną solidarnością etniczną:

Cyganie rumuńscy (10 osób): sklasyfikowani po linii obywatelstwa jako „Rumuni”, grupa płciowo mieszana, rozpiętość wieku 16-30 lat. Wyznanie prawdopodobnie prawosławne („ortodoksja”), ale często nazywane katolicyzmem. Grupa solidarna etnicznie, bardzo istotne są w niej więzi pokrewieństwa. Przynajmniej połowa informatorów tworzy jedną rodzinę, jest to bowiem trzech braci z żonami. Drugą rodzinę tworzy dwóch braci, przy czym tylko jeden ma małżonkę. W Polsce przebywają zwykle od kilku lat, język polski znają słabo. Trudnią się żebractwem (kobiety) i nielegalnym handlem oraz pracą dorywczą (mężczyźni). Charakterystyczne dla respondentów jest zwodzenie w rozmowie, unikanie odpowiedzi, wypytywanie, próby wykorzystania czy wyłudzenia pieniędzy (Chwieduk 2012).

Grecy (4 osoby): w większości mężczyźni stanu wolnego, tylko jedna kobieta (zaręczona), rozpiętość wieku 28-43 lat, zwykle prawosławni (jeden przypadek agnostyka), ale niepraktykujący. Wszyscy respondenci pracują jako lektorzy na UAM. Grupa bardzo zżyta, nieulegająca polonizacji, nieużywająca języka polskiego, utrzymująca stały kontakt z ojczyzną.

\section{"Zachód"}

Cudzoziemcy pochodzący z Europy zachodniej i północnej oraz obu Ameryk pozostają ze sobą w stosunkowo bliskich kontaktach. Czynnikiem jednoczącym - poza językiem angielskim jako lingua franca - jest przede wszystkim kosmopolityczna profesja biznesmana (Schmidt, Sydow 2012) pociągająca za sobą tradycyjny model rodziny - mąż pracuje, kobieta zajmuje się domem i dziećmi. Kobiety tworzące formalne organizacje interetniczne (międzynarodowe) i działające w nich - na przykład w International Ladies Club (ILC) czy Parents-Teacher Organization (PTO) - stanowią dodatkowy zwornik całości bloku. Chociaż istnieje nieformalny międzynarodowy klub mężczyzn, to jednak mężczyźni mają tendencję do tworzenia panetnicznych (ponadnarodowych) stowarzyszeń biznesowych po linii języka codziennej komunikacji, co organizuje zróżnicowanie bloku na segmenty i różnicuje profesję lektora (zob. Bloch 2012). Mimo że pewne bloki wiąże protestantyzm (ogólnie lub konkretne wyznanie) bądź rzymski katolicyzm, wydaje się, że znaczenie ma na ogół chrześcijaństwo, co uwidacznia się w działalności Poznań International Church; mimo tego dość mocno zaznacza się ateizm. 
Segment anglojęzyczny zrzesza cudzoziemców z Wysp Brytyjskich i Ameryki Północnej, dla których język angielski jest językiem rodzimym. $Z$ reguły są to niepraktykujący protestanci, na tym tle wyróżniają się tylko będący katolikami Irlandczycy. Stosunkowo często pracują jako lektorzy, profesja biznesmana rzadziej spotykana.

Brytyjczycy (7 osób): niemal sami Anglicy, głównie mężczyźni wieku 33-58 lat. $\mathrm{Z}$ reguły wykształcenie wyższe, tylko w jednym przypadku średnie. $\mathrm{W}$ większości osoby niereligijne, tylko jedna $\mathrm{z}$ kobiet jest praktykującą chrześcijanką (anglikanką?). Z reguły w związkach (także małżeńskich) z reprezentantami narodowości polskiej, jeden przypadek małżeństwa w obrębie własnej grupy etnicznej. Większość naucza języka angielskiego: zwykle w szkołach językowych, rzadziej na UAM lub prywatnie. Pozostali tworzą niestandardową rodzinę biznesmana, w której pracuje nie tylko mężczyzna, ale także małżonka - jako pedagog (socjoterapeuta) - za wynagrodzenie w Wielkiej Brytanii, w Polsce zaś na zasadzie wolontariatu. Znajomość języka polskiego słaba.

Na tym tle Szkot nie różni się właściwie niczym od Anglików: 27 lat, niepraktykujący protestant, w związku małżeńskim z Polką, pracuje jako nauczyciel języka angielskiego w szkole podstawowej oraz specjalista ds. marketingu w hostelu. Znajomość języka polskiego dobra.

Irlandczycy ( 2 osoby): katolicy, choć raczej niepraktykujący, pod każdym innym względem (płeć, wiek i zawód) diada zróżnicowana. Samotny 43-letni lektor języka angielskiego, przebywający w Polsce ledwie 3 miesiące, oraz 27-letnia bizneswoman mieszkająca w Poznaniu ponad 2 lata, nieaktywna członkini ILC (jako osoba pracująca), w związku na odległość z Włochem mieszkającym w Anglii.

Kanadyjczyk: 30 lat, niewierzący, bliżej nieokreślone korzenie „brytyjskie”, w związku z Polką, lektor języka angielskiego, polski zna słabo, kontakty głównie $\mathrm{z}$ anglojęzycznymi native speakerami.

Amerykanie (6 osób): grupa zmaskulinizowana (tylko jedna kobieta), zwykle w wieku 24-33 lat, rzadziej starsi (45 i 57 lat), wykształcenie wyższe. Religijnie zróżnicowani, chociaż na ogół są to religie monoteistyczne, zwykle chrześcijańskie (baptyzm, protestantyzm, konwersja na katolicyzm z ewangelicyzmu, katolik), w jednym przypadku judaizm, w innym - trzy monoteizmy naraz („,uniwersalista Abrahama"); nie potwierdzono mormonizmu. Co do zasady są to osoby niepraktykujące, ale w tym gronie znajduje się: świecki misjonarz katechizujący w duchu baptyzmu, osoba głęboko uduchowiona wierząca w „jedność dzieci Abrahama" i medium, a także osoba zainteresowana sprawami Kościoła w Polsce.

Większość naucza języka angielskiego: zwykle jako lektorzy pracujący na UAM ( w tym doktorant polonistyki), ale też w szkole językowej lub prywatnie. Ich biografia jest różna, powtarza się w nich jednak motyw bezpośredniego kontaktu z Polakami - zwykle w krajach trzecich - owocujący miłością lub przyjaźnią, które przyciągnęły ich do Polski. Dwóch Amerykanów (muzyk i historyk) przyjechało 
do Polski w ramach stypendium Fullbrighta dla asystentów językowych, a jeszcze inny jest polonistą, który przyjechał na studia do Polski. Większość z nich pozostaje w związkach z Polkami (bez partnera pozostaje kobieta i jeden z mężczyzn).

Segment skandynawski tworzą niepraktykujący protestanci mówiący językami skandynawskimi. Solidarność panetniczna strukturyzowana szczególnie poprzez działalność Polsko-Skandynawskiej Izby Przemysłowo-Handlowej.

Duńczycy (3 osoby): typowa rodzina biznesmana: małżeństwo w wieku 60 i 65 lat oraz najmłodszy syn w wieku 17 lat. Niepraktykujący protestanci. W Polsce mieszkają od 7-8 lat. Kontakty z innymi cudzoziemcami utrzymywała głównie żona: przez szkołę podstawową British School (w tym PTO) i ILC, ale kontakty te osłabły wraz z podjęciem przez syna nauki w szkole średniej International School of Poznań. Sporadyczne kontakty z anglojęzycznymi sąsiadami. Przede wszystkim utrzymują kontakty z rodziną w Danii (wzajemne odwiedziny, wspólne wycieczki).

Szwed: ponad 40 lat, niepraktykujący protestant, biznesmen, mieszkający pod Poznaniem z rodziną. Żona należy do ILC, dzieci uczą się w British School. Bierze udział w spotkaniach nieformalnego międzynarodowego klubu mężczyzn. Należy także do Polsko-Skandynawskiej Izby Przemysłowo-Handlowej, utrzymując bliskie kontakty z Polakami.

Segment niemieckojęzyczny tworzą cudzoziemcy posługujący się językiem niemieckim, zwykle będący niepraktykującymi ewangelikami. Z reguły dominującą tożsamością zawodową jest profesja lektora.

Niemcy (8 osób): przewaga mężczyzn, wykształcenie wyższe, niepraktykujący ewangelicy. Większość respondentów w stanie wolnym, nieliczni w związkach na odległość z osobami narodowości niemieckiej lub polskiej.

Zdecydowana większość respondentów to lektorzy języka niemieckiego zatrudnieni na UAM i w DAAD (Niemiecka Centrala Wymiany Akademickiej), są w bardzo różnym wieku (27-70 lat). Wielu z nich przebywało wcześniej za granicą, także w Polsce, przyjazd tutaj był świadomie podjętą decyzją; szczególny przypadkiem jest osoba urodzona w Opolu, należąca do rodziny późnych przesiedleńców. W Polsce mieszkają oni zwykle od wielu lat, chociaż zdarzają się w tym względzie wyjątki (jedna z osób mieszka w Polsce ledwie 3 miesiące). Poza jednym wyjątkiem wszyscy posługują się językiem polskim na dość wysokim poziomie i utrzymują kontakty przede wszystkim z osobami narodowości polskiej. Pewne cechy wspólne z tą grupą ma 22-letni student medycyny, pochodzenia polskiego, w związku z Polką.

Mniejszość wśród respondentów stanowią biznesmeni. Z pozyskanych informacji wynika, że to jest to grupa wyraźnie niedoreprezentowana liczebnie, a powodem tego jest bardzo aktywne życie zawodowe potencjalnych respondentów i niechęć do integrowania się. Niemieccy biznesmeni, z reguły mężczyźni, to 
$\mathrm{z}$ jednej strony osoby samotne, spędzające całe dni w pracy (w takich firmach jak Volkswagen, Man, Solaris), a z drugiej strony osoby, które czas wolny spędzają z rodzinami w domach poza Poznaniem. Cel zorganizowania środowiska niemieckich biznesmanów postawiło przed sobą Polsko-Niemieckie Koło Gospodarcze w Poznaniu (Deutsch-Polnischer Wirtschaftskreis in Poznań), które podejmuje współpracę $\mathrm{z}$ analogiczną organizacją holenderską.

Austriaczka: 41 lat, niewierząca, lektorka języka niemieckiego, zamężna z „pół-Polakiem, pół-Niemcem”. Konaty zawodowe z niemieckimi lektorami, kontakty towarzyskie z kilkoma niemieckimi biznesmenami.

Segment niderlandzki tworzą cudzoziemcy posługujący się językiem niderlandzkim, z reguły ateiści względnie niepraktykujący katolicy. Solidarność (pan)etniczna wzmacniana poprzez spotkania towarzyskie $\mathrm{w}$ ramach działającej nieformalnie grupy Holendrów. Formalnie działa natomiast Netherlands-Polish Business Club Wielkopolska, w ramach którego dokonuje się uzawodowienie etniczności.

Holendrzy (7 osób): grupa z niewielką przewagą mężczyzn, przy czym stosunkowo często przebywają w Polsce całe małżeństwa (w jednym przypadku mąż jest Belgiem); pojedyncze są przypadki związku z Polką, singla i rozwodnika. Osoby zwykle w wieku 38-40 lat, pojedynczy przypadek przekroczenia 50 lat. Bardzo duże znaczenia mają kontakty rodzinne, szczególnie z dziećmi, jako że stosunkowo często na życzenie rodziców dzieci odbywają edukację za granicą, przede wszystkim w Berlinie. W zdecydowanej większości ateiści, ale jeden przypadek niepraktykującej katoliczki (żona Belga) i jeden praktykującej protestantki. Mężczyźni mają zwykle wykształcenie wyższe, często inżynierskie, kobiety najczęściej mają skończoną szkołę policealną. Mężczyźni to pracownicy wysoko wykwalifikowani, z reguły biznesmeni na czasowym kontrakcie, w jednym przypadku lektor języka. Kobiety zwykle nie pracują zawodowo, choć odnotowano przypadek bizneswoman. Przebywają w Polsce od kilku lat (2-5, w jednym przypadku 7 lat). Większość osób podejmuje naukę języka polskiego.

Wielu mężczyzn działa w ramach Netherlands-Polish Business Club, istnieje jednak spora grupa mężczyzn - oraz Holenderka zamężna z Belgiem - którzy nie utrzymują kontaktów towarzyskich z Holendrami, jako że nie odpowiada im biznesowy charakter spotkań lub czują antypatię wobec konkretnych osób i w ogóle nie prowadzą życia towarzyskiego. Bardziej aktywne towarzysko są kobiety, które nie tylko organizują spotkania w obrębie własnej grupy narodowej, ale także działają aktywnie w ILC i PTO (jedna z kobiet przez cztery lata pełniła funkcję zastępcy przewodniczącego rady rodziców). To kobiety zainicjowały spotkania towarzyskie w gronie międzynarodowym, w których toku wyłonił się nieformalny międzynarodowy klub mężczyzn.

Belgowie (Flamandowie?) (2 osoby): diada płciowo mieszana, w podobnym wieku (35 i 40 lat), wykształcenie wyższe, środowisko wielojęzyczne, niepraktykujący katolicy. Model rodziny „biznesowy”: mężczyzna na kontrakcie, żona 
nie pracuje zawodowo i opiekuje się dziećmi. Drugie z małżeństw ma charakter mieszany, zostało bowiem zawarte z Holenderką. Mimo że oboje mają podwójne obywatelstwo, zachowują dystans wobec poznańskich Holendrów, którzy proponowali im dołączenie do spotkań towarzyskich. Przykład tej rodziny pokazuje, że szkoła podstawowa British School stanowi ognisko sieci społecznej cudzoziemców tworzących środowisko biznesowe: matki uczniów przynależą do ILC, w działalność szkoły angażują się także ojcowie uczniów - Belg pełnił przez rok funkcję przewodniczącego rady rodziców. Mężczyźni dodatkowo utrzymują z cudzoziemcami kontakty zawodowe, chyba rzadziej towarzyskie.

Południowy Afrykańczyk: 31 lat, niereligijny, wykształcenie wyższe, lektor języka afrikaans, zatrudniony na UAM. Utrzymuje bliskie kontakty z osobami posługującymi się afrikaans i językiem niderlandzkim, a więc Holendrami i Belgami (Flamandami). Obywatelstwo i narodowość określone jako „RPA”, prawdopodobnie (identyfikuje się i jest identyfikowany jako) Biały.

Segment francuskojęzyczny poprzez Belgów lokuje się w bezpośrednim sąsiedztwie segmentu niderlandzkiego, zachowuje jednak zupełną autonomię, o której stanowi odmienny język i profesja lektora.

Belgijka (Walonka?): młodsza od innych Belgów (27 lat), jest singielką. Przebywa w Polsce na stypendium ambasady belgijskiej, a co najważniejsze - pracuje na UAM jako lektorka języka francuskiego i to właśnie może wskazywać na jej odrębną narodowość (wydaje się, że nie zna niderlandzkiego, zna natomiast angielski).

Francuzka: 35 lat, pochodzenia polskiego, mówiąca dobrze po polsku, rozwiedziona z Polakiem, lektorka zatrudniona na UAM.

Segment hiszpańskojęzyczny tworzą cudzoziemcy, dla których językiem rodzimym jest hiszpański, a dominującym typem tożsamości zawodowej profesja lektora. Społeczność latynoska jest bardzo żyta, solidarność panetniczna wzmacniana organizacyjnie poprzez działalność Centro Hispano. Wyznanie katolickie, ale bardzo rzadko są to osoby praktykujące, przy czym podkreślają, że są ludźmi uduchowionymi. Zwykle lektorzy języka hiszpańskiego, rzadziej języków regionalnych Hiszpanii, takich jak kataloński lub baskijski. Zdecydowana większość w związkach z przedstawicielami narodowości polskiej.

Hiszpanie (7 osób): grupa zróżnicowana narodowościowo. W tym gronie z całą pewnością znajduje się Katalończyk i Baskijka, jeden z informatorów jest pół-Galicyjczykiem po matce (mówi po galicyjsku i afirmuje odrębność Galicji), a inny może być Aragończkiem (pochodzi z Saragossy). W innych przypadkach brak informacji.

Grupa bez wyraźnego profilu płciowego, najczęściej osoby trzydziestokilkuletnie (wyjątkowo w wieku 61 lat), wyższe wykształcenie (prawo, weterynaria, ekonomia, ochrona środowiska, logistyka morska). Z reguły ateiści lub nieprakty- 
kujący katolicy, tylko jeden z respondentów określił się mianem praktykującego. Zwykle w związkach z osobami narodowości polskiej (w tym przypadek rozwodu z Hiszpanką), ale także pojedyncze przypadki małżeństwa pomiędzy Hiszpanami i z lektorką języka łotewskiego. Często są to osoby przebywające w Polsce od dłuższego czasu (6-12 lat), mówiące dobrze po polsku; osoby mieszkające w Polsce krócej (do 2 lat) znają język przynajmniej na poziomie komunikatywnym.

Pod względem zawodowym połowa grupy to biznesmeni: dyrektor firmy w branży rolniczej; właściciel sklepu z winami i produktami hiszpańskimi; w jednym przypadku ,interesy” (brak bliższych danych) prowadzi małżeństwo. Drugą połowę grupy stanowią lektorzy, większość zatrudniona na UAM, jedna osoba zarobkuje nielegalnie, ucząc języka.

Jeden z biznesmenów uczestniczy okazjonalnie w spotkaniach Centro Hispano. Osoba zarobkująca nielegalnie nauczaniem hiszpańskiego nie utrzymuje kontaktów z Hiszpanami, ponieważ są to studenci lub biznesmeni, a on sam nie należy do żadnej z tych kategorii. Współlokatorką Baskijki jest Rosjanka.

Kubanki ( 2 osoby): w wieku średnim (34 i 61 lat), w Polsce od wielu lat (16 i 34), w jednym przypadku pochodzenie polskie, w związkach małżeńskich z Polakami, znajomość języka polskiego bardzo dobra. Profil zawodowy zróżnicowany: lektorka języka hiszpańskiego na UAM oraz restauratorka. Przynależność do Centro Hispano.

Wenezuelka: 35 lat, w związku małżeńskim z Polakiem, lektorka języka w szkole językowej. Katoliczka, wierząca w Boga, ale nie w Kościół. Nie zna języka polskiego, poza pracą posługuje się językiem angielskim.

Kolumbijka: 40 lat, w związku małżeńskim z Polakiem, lektorka pracująca na UAM, w Polsce od 20 lat, polski zna bardzo dobrze.

Chilijczyk: 33 lata, w związku małżeńskim z Polką, bezrobotny szukający pracy jako lektor, praktykujący katolik. Zdystansowany wobec Centro Hispano.

Pewnym wyjątkiem w tej grupie jest Meksykanin: 47 lat, obywatelstwo meksykańskie i amerykańskie, wojskowy na emeryturze, uczy języka angielskiego (rzadziej hiszpańskiego). Rozwiedziony z Meksykanką, obecnie w związku z Polką. Niepraktykujący katolik, ale głęboko uduchowiony. Rodzina transnarodowa. Wykluczony z nieformalnej grupy międzynarodowej.

Na pograniczu tego segmentu znajdują się Brazylijczycy (2 respondentów): małżeństwo, typowa rodzina biznesmenów, która jednak nie utrzymuje kontaktów towarzyskich. Żona jest mało aktywnym członkiem ILC, mężczyzna utrzymuje z innymi cudzoziemcami głównie kontakty zawodowe, posługując się hiszpańskim. W przestrzeni publicznej posługują się językiem angielskim, portugalskiego używają tylko w domu.

Do żadnego z segmentów - jak się wydaje - nie przynależą Włosi (4 osoby): grupa mężczyzn, zwykle w wieku 32-35 lat, w jednym przypadku 47 lat. Połowa badanej grupy to praktykujący katolicy, a połowa buddyści. Większość Włochów jest w związkach z Polkami i mówi bardzo dobrze po polsku, w tym przypadek 
polskiego pochodzenia po matce. Małżeństwo w obrębie własnej grupy narodowej jest wyjątkiem i tylko wówczas występuje słaba znajomość polskiego. Wszyscy mają wykształcenie wyższe (w tym $\mathrm{z}$ doktoratem). Większość pracuje jako biznesmeni, przy czym $\mathrm{w}$ jednym przypadku działalność gospodarcza polega na nauce języka włoskiego; wyjątkiem w tej grupie jest praca w radiu. Wszyscy przywiązują ogromną wagę do włoskiej kuchni - gotują sami w domu, na mieście jadają niezwykle rzadko i tylko w wybranych lokalach. Włosi nie wykazują solidarności etnicznej, jedynie Włoch pochodzenia polskiego utrzymuje kontakty z przedstawicielami narodowości włoskiej.

\section{"Afryka i Azja"}

Blok afrykańsko-azjatycki ma charakter parafiletyczny, którego wspólnym mianownikiem jest odmienność rasowa cudzoziemców i egzotyka językowa (języki nieindoeuropejskie, w odróżnieniu od cudzoziemców z obu Ameryk); brak tu konkretnej wspólnoty tożsamości. Blok tworzą trzy wyraźne segmenty charakteryzujące się stosunkowo silnymi solidarnościami interetnicznymi, które w dwóch przypadkach są tworzone na „trudno dostępnej” (Chwieduk 2012) płaszczyźnie religijnej (muzułmanie oraz zielonoświątkowcy), w jednym przypadku zaś na płaszczyźnie zawodowej (lektorzy). Wydaje się znamienne, że zróżnicowanie to harmonizuje (przynajmniej częściowo) z polskimi wyobrażeniami grup etniczno-rasowych: „Arabami”, „Murzynami” i „Chińczykami” (Nawrocki 1990). Pomimo odmienności rasowej niektórzy zasiedziali obcokrajowcy utożsamiają się z kulturą polską i mają polskie obywatelstwo lub starają się je uzyskać.

Segment muzutmański organizuje religia, zrzeszając cudzoziemców z Afryki Arabskiej oraz Bliskiego Wschodu. Są to z reguły osoby praktykujące, często silniej zaangażowane religijnie niż w kraju pochodzenia. Czynienie z islamu kluczowego wskaźnika tożsamości świadczy najwyraźniej o potrzebie ureligijnienia etniczności w kraju postrzeganym jako katolicki. Oczywiście od tej reguły zdarzają się wyjątki: z całą pewnością niepraktykującym muzułmaninem jest mocno spolonizowany Libijczyk, prawdopodobnie taką osobą jest także bizneswoman z Iranu. Niemal wszyscy cudzoziemcy w tej grupie to mężczyźni, większość pracuje w branży gastronomicznej (Adamowicz, Kochaniewicz 2012) w restauracjach tureckich, co w praktyce oznacza dodatkowo upłciowienie i uzawodowienie islamu. Segment ten ma również swoją komponentę rasową w postaci stereotypu „Araba”.

Turcy (16 osób): grupa mężczyzn, zdecydowanie dominująca liczebnie (według pozyskanych informacji w Poznaniu mieszka ich 300). Wyznanie - islam; jeden $\mathrm{z}$ respondentów stał się w Polsce bardziej religijny i przestrzegający postu, namawia swoją partnerkę do przejścia na islam. Turcy przeważnie znajdują się w związkach partnerskich lub małżeńskich (osoby starsze) z Polkami, nieliczni są 
stanu wolnego. Większość Turków uczy się języka polskiego i zna go przynajmniej na poziomie komunikatywnym. Około $1 / 3$ respondentów zna język bardzo dobrze, co zwykle dotyczy osób starszych, mieszkających w Polsce od wielu (7-9) lat.

Najliczniejszą grupą respondentów są dwudziestokilkuletni studenci, głównie zarządzania, albo pracownicy gastronomii, którzy przyjechali do Polski na zaproszenie członka rodziny lub znajomego otwierającego tu własny interes; zwykle przebywają w Polsce od kilku lat. Osoby starsze (w wieku 27-45 lat) prowadzą aktywne życie zawodowe. W większości to właściciele restauracji lub kebabiarni, rzadziej lektorzy, współwłaściciele firmy z tekstyliami, rezydenci biura podróży.

Tureckie restauracje i kebabiarnie stanowią przestrzeń, w których manifestuje się turecka etniczność. Z jednej strony, należy mówić o sposobie spędzania wolnego czasu poza domem $\mathrm{w}$ towarzystwie, $\mathrm{z}$ drugiej strony, oczywiście, miejsca te stanowią zagęszczenia cudzoziemców pochodzenia tureckiego i wyznawców islamu w ogóle. Co więcej, poza statusem „drugiego domu”, mają one także status "miejsca pracy” dla wielu muzułmanów - nie tylko Turków, ale także Palestyńczyków i Algierczyków - a nawet dla Indusów.

Palestyńczycy (2 osoby): mężczyźni, w wieku 28 i 33 lata, muzułmanie, mający niepalestyńskie obywatelstwa: jordańskie lub egipskie, co w tym drugim przypadku stanowi zdecydowanie kluczowy komponent samoidentyfikacji. W związkach małżeńskich z Polkami (w tym z pół-Palestynką), wliczając w to wcześniejszy formalny (według prawa polskiego) rozwód z Polką i zawarcie kolejnego małżeństwa nieformalnego (według prawa muzułmańskiego) z kolejną partnerką polskiej narodowości. Jeden z mężczyzn mieszka w Polsce od 15 lat - przyjechał tu na studia ekonomiczne, obecnie naucza języka arabskiego, język polski zna dobrze. Drugi przebywa w Polsce od kilku lat, nie skończył studiów historycznych na Uniwersytecie w Egipcie, w Polsce nie studiuje, bo zbyt słabo zna język polski; obecnie pracuje w kebabiarni.

Marokańczycy (2 osoby): mężczyźni, praktykujący muzułmanie, członkowie Centrum Kultury Muzułmańskiej w Poznaniu (w tym imam), mający wykształcenie wyższe (jeden kontynuuje edukację w Polsce), bardzo dobrze mówiący po polsku. Pod każdym innym względem grupa zróżnicowana.

Algierczyk: 30 lat, żonaty z Polką, muzułmanin, wykształcenie wyższe, pracuje jako kelner w restauracji, język polski zna słabo.

Libijczyk: starszy wiekiem, od 22 lat w Polsce, żonaty z Polką, niepraktykujący muzułmanin, zasiedziały, utożsamiający się z kulturą polską i biegle posługujący się językiem (myśli po polsku, przebudzony ze snu mówi po polsku), właściciel sklepu-bistro arabskiego.

Iranka: 30 lat, obywatelstwo irańskie i niemieckie, bizneswoman na kontrakcie, język polski zna słabo. Prawdopodobnie niepraktykująca muzułmanka.

Poza segmentem, lecz w jego bezpośrednim sąsiedztwie znajdują się Indusi (4 osoby): mężczyźni, zwykle trzydziestukilkuletni (jedna osoba 24 lata), wszyscy żonaci z Polkami, znajomość języka polskiego zazwyczaj komunikatywna. Profil 
zawodowy grupy mieszany, ale szczególne znaczenie może mieć praca w tureckiej gastronomii (pozostali to pracownik korporacji w branży IT i lektor na UAM). Większość respondentów mieszka w Polsce kilka lat (3-5 lat), planują pozostanie w Polsce; tylko osoba przebywająca tu najkrócej zamierza wyjechać. Grupa ta dużą wagę przykłada do ostrej kuchni indyjskiej.

Segment zielonoświątkowy organizuje religia, zrzeszając cudzoziemców w większości mężczyzn - pochodzących z zachodniej i wschodniej krajów Afryki. Segment ma swoją komponentę rasową w postaci stereotypu „Murzyna” czy „czarn(oskór)ego”.

Nigeryjczycy (8 osób): prawie bez wyjątku mężczyźni w podobnym wieku (29-39 lat). Większość studiuje (lub już ma wykształcenie wyższe) na kierunkach ekonomicznych (zarządzenie przedsiębiorstwami, zarządzenie biznesem, biznes międzynarodowy); studia były zresztą głównym powodem przyjazdu do Polski. Pozostali pracują w sektorze edukacji lub, w jednym przypadku, w biznesie; wszyscy mają wykształcenie wyższe. Niemal połowa respondentów pozostaje w związkach z Pol(a)kami. Większość z nich przynależy do Kościoła zielonoświątkowego, w którym są bardzo aktywni - jeden $\mathrm{z}$ respondentów pełni funkcje pastora.

Kenijka: 24 lata, studentka stomatologii, po polsku mówi dobrze, utrzymuje kontakty z innymi Kenijczykami, a także Afrykanami należącymi do Kościoła Zielonoświątkowców. Gotuje kenijskie potrawy.

Kameruńczyk: 30 lat, wykształcenie wyższe, stanu wolnego, prawdopodobnie zielonoświątkowiec.

Na pograniczu segmentu znajduje się Etiopczyk: 45 lat, żonaty z Polką, w Polsce zasiedziały (od 24 lat), pracuje na UAM jako lektor, doskonale zna język polski; świadomie nie identyfikuje się z żadnym wyznaniem.

Segment azjatycki charakteryzuje się komponentą rasową w postaci stereotypu "Chińczyka” lub szerzej „,̇ółtka”/,skośnookiego”. Solidarność interetniczna powstaje głównie na płaszczyźnie zawodowej, gdyż względna większość cudzoziemców to lektorzy (Bloch 2012), aczkolwiek w liczbach bezwzględnych dominują Tajwańczycy studiujący na Uniwersytecie Medycznym (Stanisz 2012). Chociaż wszyscy lektorzy pracują na dawnym ${ }^{8}$ Wydziale Neofilologii, są oni afiliowani w dwóch różnych jednostkach umiejscowionych w różnych miejscach Poznania: Instytucie Językoznawstwa oraz Katedrze Orientalistyki (Chińczycy, Japonki). W bliskich kontaktach zawodowych i towarzyskich pozostają jedynie pracownicy Instytutu Językoznawstwa (z wyłączeniem Indonezyjczyków).

Południowi Koreańczycy (3 osoby): grupa płciowo mieszana, rozpiętość wieku 29-44 lat, ukończone studia wyższe (w tym profesor lingwistyki), lektorzy pracujący na UAM, raczej niewierzący, chociaż jedna z osób określa się jako chrześ-

8 Przed reformą szkolnictwa wyższego i nauki w 2019 roku. 
cijanka. Większość przebywa dłuższy okres w Polsce (co najmniej 5 lat), ale jedna osoba przebywa tu od kilku miesięcy. Znajomość języka raczej podstawowa lub żadna, z wyjątkiem osoby zamężnej z Polakiem. Wszyscy respondenci zdystansowani, a nawet nieufnie nastawieni wobec badań.

Tajka: 24 lata, lektorka na UAM, stanu wolnego, nieufnie nastawiona do badań.

Wietnamczyk: 29 lat, stanu wolnego, niewierzący, lektor pracujący na UAM (ukończone studia licencjackie na historii). Na UAM pracuje także jego ojciec. Po polsku mówi na podstawowym poziomie.

Indonezyjczycy ( 2 osoby): różnej płci i wyznania (agnostyk i katoliczka), ale w podobnym wieku: 30 i 38 lat. Z zawodu lektorzy pracujący na UAM, a jednocześnie jeden $\mathrm{z}$ respondentów jest projektantem i współpracownikiem ambasady. W Polsce przebywają od 5-10 lat, znajomość języka polskiego co najmniej komunikatywna, w związkach z osobami narodowości polskiej.

Na pograniczu segmentu (poza Instytutem Językoznawstwa) sytuują się:

Japonki (4 osoby): kobiety, trzydziestokilkulatki, brak obszerniejszych danych na temat wyznania (jedna $\mathrm{z}$ nich jest katoliczką). $Z$ reguły lektorki na UAM, zamężne z Polakami, mieszkające w Polsce 10-12 lat, dość dobrze znające język. Powody przyjazdu do Polski różne, powtarza się jednak motyw sprzeciwu wobec tradycyjnej roli kobiety w społeczeństwie japońskim. Doświadczenie szoku kulturowego: Polacy są bardziej ekspresyjni emocjonalnie, niestrawne jedzenie (tłuste i mięsne), brak słońca.

Wyjątkiem w tym gronie jest żona japońskiego biznesmena, należąca do ILC. Z pozyskanych informacji wynika, że w Bridgestone pracuje czterech Japończyków, którzy do Polski przyjechali z żonami. Są zamknięci, rozmawiają ze sobą tylko po japońsku.

Chińczycy (3 osoby): Grupa respondentów zróżnicowana ze względu na płeć, wiek i zajęcie, a także miejsce pochodzenia (wszyscy pochodzą z prowincji wschodnich); w jednym przypadku wskazana narodowość Han. W Poznaniu mieszka dużo większa grupa Chińczyków (widoczna na chińskim portalu społecznościowym QQ), zespolona więzami pokrewieństwa i przyjaźni, którą można podzielić na trzy podgrupy.

Pierwsza to studenci i lektorzy na sinologii UAM, a jednocześnie pracownicy Instytutu Konfucjusza, któremu partneruje Uniwersytet w Tianjin, skąd większość z nich pochodzi (tylko studentka Akademii Muzycznej wywodzi się z prowincji Guangdong); Chińczycy ze środowiska akademickiego często zawierają związki małżeńskie z osobami narodowości polskiej. Druga podgrupa to 40-50 Chińczyków pracujących poza środowiskiem akademickim: zwykle w wieku 20-40 lat, często małżeństwa'; prowadzą oni chińskie markety lub restauracje, pracują jako

9 Ich dziećmi pozostałymi w Chinach opiekują się zwykle dziadkowie. Rodzice odwiedzają je przynajmniej raz w roku przy okazji wizyt biznesowych. Jest to zatem zjawisko paralelne wobec tzw. eurosieroctwa. 
kucharze $\mathrm{w}$ orientalnych restauracjach (niekoniecznie chińskich), zajmują się importem towarów z Chin (dodatkowo trudnią się tym niektórzy wykładowcy) lub handlem na straganach; większość pochodzi z peryferyjnych prowincji: Zhe jiang i Fu jian. Poza stałymi rezydentami w Poznaniu pojawiają się okresowi pracownicy budowlani, pochodzący z prowincji Heilongjiang. Wśród Chińczyków pochodzących z jednej prowincji istnieją dobrze rozwinięte sieci transnarodowe, nierzadko aktywowane w celu dostarczania pigułek poronnych (konflikt między prawem chińskim i polskim).

Cechą charakterystyczną tej grupy jest kontestowanie wysokiego stopnia kontroli sprawowanej nad obywatelami przez państwo chińskie i jego agend (takich jak Instytut Konfucjusza). Chińska studentka do woli korzysta w Polsce z zakazanych w Chinach portali internetowych Facebook i YouTube, chińscy wykładowcy utrzymują kontakty z wykładowcami z Tajwanu (za co otrzymują naganę w konsulacie) lub rozwodzą się z żonami pozostałymi w Chinach i mają dzieci z Polkami (co ukrywają przed chińskim pracodawcą). Zapewne z tego względu część imigrantów decyduje się na nielegalny pobyt w Polsce: niszczą swoje paszporty, w razie kontroli pożyczając sobie paszporty z aktualną wizą pracowniczą lub kartę pobytu, albo ubiegają się o status bezpaństwowca czy kartę pobytu, podając się za członka prześladowanego w Chinach ruchu Falun Gong. Chińczycy nie mają problemów żywieniowych, nie przeszkadza im kuchnia polska (ani quasi-chińska).

Autonomiczną częścią segmentu są osoby sklasyfikowane po linii obywatelstwa jako Tajwańczycy (5 osób): mężczyźni, studenci stomatologii lub medycyny (w tym jeden już skreślony), pochodzenia tajwańskiego, spośród których jednak tylko dwóch ma obywatelstwo tajwańskie lub chińskie, większość zaś legitymuje się obywatelstwem amerykańskim lub kanadyjskim. W istocie wśród szacowanych 400 Tajwańczyków zamieszkujących w Domu Studenckim „Eskulap”, większość stanowią imigranci z Kanady lub z USA. Płeć respondentów nie oddaje natomiast zróżnicowania płciowego $\mathrm{w}$ grupie. Tak samo jest $\mathrm{z}$ wyznaniem: respondentami byli albo chrześcijanie (mniej lub bardziej praktykujący), albo ateiści, mimo że większość Tajwańczyków to niepraktykujący buddyści. Na zewnątrz jest to grupa hermetyczna, niewyrażająca woli integracji ani działalności organizacyjnej. O specyfice tej grupy stanowią nawyki żywieniowe - polską kuchnię postrzegają jako mdłą, w związku z czym czują potrzebę przygotowywania tajwańskich potraw. Dla wygody gotują i biesiadują grupowo, co daje też okazję do wspólnego spędzania czasu i rozmów w języku mandaryńskim.

\section{Czy w Poznaniu mamy grupy etniczne? (Zakończenie)}

Bezsprzecznie socjoekonomiczne sektory biznesu, handlu i usług, edukacji, a także pole studiów oraz instytucje (w tym „wolni strzelcy”) stanowią niezwykle istotne wymiary heterogeniczności kulturowej. Wnioski przedstawione w ramach 
dyskutowanego projektu (Bloch i in. 2012) wymagają jednak uzupełnienia, jako że heterogeniczność tę kształtują także, jeśli nie przede wszystkim, tożsamości kulturowe. Dokonana analiza wskazuje, że etniczność/narodowość cudzoziemców w praktyce życia codziennego ustępuje pola solidarnościom ponadetnicznym czy interetnicznym, konstytuującym poszczególne segmenty zgrupowane w trzy wielkie bloki. Podkreślam, że nie mówię tutaj o płaszczyźnie teoretycznej czy metodologicznej, ale o płaszczyźnie empirycznej, chociaż oczywiście od tej reguły zdarzają się wyjątki (Romowie/Cyganie rumuńscy, Turcy, Grecy, część Chińczyków i Japończyków, chyba też Serbowie), a jednocześnie niektórzy cudzoziemcy deklarują posiadanie etniczności polskiej.

Chociaż trudno przecenić wagę sytuacyjnych autoidentyfikacji, a więc czynników subiektywnych, warto przyjrzeć się także czynnikom o bardziej obiektywnym charakterze. I tak wśród poznańskich cudzoziemców etniczność/narodowość rzadko manifestuje na poziomie mezo, poprzez grupę etniczną w pełnym znaczeniu tego słowa; zwykle daje się ona uchwycić tylko na poziomie mikro $\mathrm{w}$ najlepszym razie przez rodzinę, w najgorszym zaś przez pojedynczą jednostkę (Barth 1994). Chociaż nie istnieje bezpośrednia zależność między liczbą respondentów a liczbą cudzoziemców określonej narodowości, to warto zwrócić uwagę, że choć wywiady przeprowadzono z reprezentantami około 60 narodowości, to $\mathrm{w}$ blisko połowie przypadków (30) wywiady przeprowadzono $\mathrm{z}$ jednym tylko przedstawicielem danej grupy etnicznej, a w kilku innych przypadkach (8) z dwoma przedstawicielami, tak więc zaledwie około $1 / 3$ przypadków spośród respondentów spełnia minimum definicyjne "grupy”.

Równie ważne jest stwierdzenie, że w większości przypadków nie można mówić o funkcjonujących w Poznaniu grupach etnicznych $\mathrm{z}$ uwagi na niespełnienie warunków biologicznej i kulturowej samoreprodukcji. Sytuacja ta występuje oczywiście - jak wyżej - kiedy mamy do czynienia z pojedynczym przedstawicielem danej narodowości, kiedy respondenci są jednej płci (lub kiedy jedna płeć jest nadreprezentowana) lub kiedy grupa jest bardzo niewielka liczebnie (nawet rodzina jest zbyt małą jednostką społeczna, by mówić o grupie etnicznej). Mniej oczywistym przypadkiem są grupy rówieśnicze, w których transmisja pokoleniowa po prostu nie istnieje, czego wzorcowym przykładem może być grupa studentów tajwańskich.

Być może najważniejsza jest jednak kwestia braku ukierunkowanych, zestandaryzowanych interakcji z Polakami, co dla Bartha (2004: 357) stanowiło zasadniczy wskaźnik społecznej organizacji grup kulturowych. Grupy i granice etniczne istnieją wtedy, kiedy dysponuje się rutynowymi sposobami tworzenia relacji społecznych, dlatego też o pakistańskich migrantach zarobkowych w Soharze Barth (1983: 41) pisał, że dopiero „zaczynają nabierać cech uformowanej kategorii etnicznej”. Nawet jeśli posłużymy się szerszym pojęciem etniczności (jako synonimu różnicy kulturowej), to nie sposób nie zauważyć, że tylko pojedyncze grupy cudzoziemców zdołały wypracować rutynowe relacje społeczne z poznaniakami 
(Polakami) i zająć „niszę etniczną”. Na pierwszym miejscu na pewno należy wymienić nie tureckich imigrantów pracujących w gastronomii (Bloch i in. 2012: 273-274) - jako że dopiero zaczynają oni tworzyć taką niszę, a ponadto stanowią fundament interetnicznego segmentu opartego na islamie - ale Romów/Cyganów rumuńskich ${ }^{10}$. O ile, pomimo wcześniejszych zastrzeżeń, byłby jeszcze sens mówić o grupie etnicznej Tajwańczyków, o tyle w pozostałych przypadkach relacje mają charakter ewidentnie pan-/interetniczny i taki sam charakter mają nisze imigracyjne (por. Waldinger 1994). Cudzoziemcy, którzy wykazują silne poczucie solidarności narodowej, jak Grecy czy mężczyźni Japończycy, trzymają się od Polaków na dystans, nie pozwalając ilościowo ani jakościowo na stworzenie relacji etnicznej.

\section{Biliografia}

Adamowicz A., Kochaniewicz A. 2012 Pracownicy branży gastronomicznej, w: Migracje a heterogeniczność kulturowa. Na podstawie badań antropologicznych $w$ Poznaniu, red. M. Buchowski, J. Schmidt, Poznań, s. 116-129.

Ardener E.

1992 Tożsamość i utożsamienie, przeł. Z. Mach, w: Sytuacja mniejszościowa i tożsamość, red. Z. Mach, A. Paluch, Kraków, s. 21-42.

2018 The Voice of Prophecy: And Other Essays, red. M. Chapman, New York-Oxford. Banks M.

1996 Ethnicity: Anthropological Constructions. London-New York. Barth F. (red.)

1969 Ethnic Groups and Boundaries: The Social Organization of Culture Difference, Oslo.

1983 Sohar. Culture and Society in an Omani Town, Baltimore-London.

Barth F.

1984 Problems in Conceptualizing Cultural Pluralism, with Illustrations from Somar, Oman, w: The Prospects for Plural Societies: 1982 Proceedings of the American Ethnological Society, red. S. Plattner, D. Maybury-Lewis, Washington, D.C., s. 77-87.

1994 Enduring and Emerging Issues in the Analysis of Ethnicity, [w:] The Anthropology of Ethnicity: Beyond 'Ethnic Groups and Boundaries', red. H. Vermeulen, C. Govers, Amsterdam, s. 11-32.

2004 Grupy i granice etniczne: społeczna organizacja różnic kulturowych, przeł. M. Głowacka-Grajper, w: Badanie kultury. Elementy teorii antropologicznej. Kontynuacje, red. M. Kempny, E. Nowicka, Warszawa, s. 348-377.

Bloch N.

2012 Imigranci-profesjonaliści w sektorze edukacji, w: Migracje a heterogeniczność kulturowa. Na podstawie badań antropologicznych w Poznaniu, red. M. Buchowski, J. Schmidt, Poznań, s. 130-150.

${ }_{10}$ Gdyby badania te odbyły się obecnie, w pierwszej trójce znaleźliby się z pewnością Ukraińcy. 
Bloch N., Buchowski M., Chwieduk A., Schmidt J.

2012 Wnioski, w: Migracje a heterogeniczność kulturowa. Na podstawie badań antropologicznych w Poznaniu, red. M. Buchowski, J. Schmidt, Poznań, s. 130-150.

Bloch N., Goździak E. (red.)

2010 Od gości do sąsiadów. Integracja cudzoziemców spoza Unii Europejskiej w Poznaniu w edukacji, na rynku pracy $i$ w opiece zdrowotnej, Poznań.

Bloch N., Main I., Sydow K. (red.)

2015 Nie dość u̇̇yteczni. Zmagania imigrantów na lokalnym rynku pracy, Poznań.

Bourdieu P.

2005 Dystynkcja. Społeczna krytyka władzy sądzenia, przeł. P. Biłos, Warszawa.

Buchowski M.,

2017 Czyściec. Antropologia neoliberalnego postsocjalizmu, Poznań.

Buchowski M., Schmidt J. (red.)

2012a Migracje a heterogeniczność kulturowa. Na podstawie badań antropologicznych w Poznaniu, Poznań.

Buchowski M., Schmidt J.

2012b Imigracja a heterogeniczność kulturowa. Perspektywa antropologiczna, w: Migracje a heterogeniczność kulturowa. Na podstawie badań antropologicznych $w$ Poznaniu, Poznań.

Chwieduk A.

2012 Imigranci z grup „trudno dostępnych”, w: Migracje a heterogeniczność kulturowa. Na podstawie badań antropologicznych w Poznaniu, red. M. Buchowski, J. Schmidt, Poznań, s. 232-270.

Chwieduk A., Schmidt J.

2012 Metodologia badań, w: Migracje a heterogeniczność kulturowa. Na podstawie badań antropologicznych w Poznaniu, red. M. Buchowski, J. Schmidt, Poznań, s. 23-52.

Czerniejewska I. (red.)

2016 Nie dość mile widziani. Zmagania imigrantów z legalizacja pobytu w Poznaniu, Poznań.

Ellen R.

2008 Klasyfikacja, przeł. M. Kruszelnicki, w: Encyklopedia antropologii społeczno-kulturowej, red. A. Barnard, J. Spencer, Poznań, s. 297-301.

Eriksen T.H.

2013 Etniczność i nacjonalizm. Ujęcie antropologiczne, przeł. B. Gutowska-Nowak, Wydawnictwo Uniwersytetu Jagiellońskiego.

Eriksen T.H., Jakoubek M. (red.)

2019 Ethnic Groups and Boundaries Today: A Legacy of Fifty Years. London, New York. Filip M.

2012 Od Kaszubów do Niemców. Tożsamość Słowińców z perspektywy antropologii historii, Poznań.

Glick Schiller N., Çă̆lar A., Guldbrandsen T.C.

2006 Beyond the Ethnic Lens: Locality, Globality, and Born-Again Incorporation, „American Ethnologist", nr 33 (4), s. 612-633.

Harrison F.V.

1995 The Persistent Power of "Race" in the Cultural and Political Economy of Racism, „Annual Review of Anthropology”, nr 24, s. 47-74. 
Moerman M.,

1965 Ethnic Identification in a Complex Civilization: Who Are the Lue?, „American Anthropologist”, nr 67 (5), s. 1215-1230.

Nagata J.A.

1974 What Is a Malay? Situational Selection of Ethnic Identity in a Plural Society, „American Ethnologist", nr 1 (2), s. 331-350.

Nawrocki J.

1990. Polskie obrazy obcych - para poznawcze komponenty stereotypów Araba, Chinczyka, Murzyna i Żyda, w: Swoi i obcy, red. E. Nowicka, t. 1, Warszawa, s. 109-152.

Okamura J.Y.

1981 Situational Ethnicity, „Ethnic and Racial Studies”, nr 4 (4), s. 452-465.

Pakieła A.

2012 Studium przypadku III: Białoruscy stypendyści Programu im. Konstantego Kalinowskiego, w: Migracje a heterogeniczność kulturowa. Na podstawie badań antropologicznych w Poznaniu, red. M. Buchowski, J. Schmidt, Poznań, s. 196-210.

Pakieła A., Przepiera Ż.

2012 Studium przypadku II: Rosyjskojęzyczni studenci skupieni wokót Wspólnoty Polskiej, w: Migracje a heterogeniczność kulturowa. Na podstawie badań antropologicznych w Poznaniu, red. M. Buchowski, J. Schmidt, Poznań, s. 188-196.

Rydzewski R.

2012 Studium przypadku I: Sprzedawcy na poznańskich bazarach, w: Migracje a heterogeniczność kulturowa. Na podstawie badań antropologicznych w Poznaniu, red.

M. Buchowski, J. Schmidt, Poznań, s. 102-116.

Schmidt J., Sydow K.

2012 Imigranci-profesjonaliści w sektorze biznesu, w: Migracje a heterogeniczność kulturowa. Na podstawie badań antropologicznych $w$ Poznaniu, red. M. Buchowski, J. Schmidt, Poznań, s. 79-98.

Stanisz A.

2012 Studium przypadku I: Tajwańscy studenci Uniwersytetu Medycznego, w: Migracje a heterogeniczność kulturowa. Na podstawie badań antropologicznych w Poznaniu, red. M. Buchowski, J. Schmidt, Poznań, s. 155-188.

Sydow K.

2017 (Nie)widzialni mieszkańcy. Dyskurs o imigrantach i roli miasta w ich wspieraniu na przykładzie Poznania, „Studia Migracyjne - Przegląd Polonijny”, nr 2 (164), s. $143-166$.

Vermeulen H., Govers C. (red.)

1994 The Anthropology of Ethnicity: Beyond 'Ethnic Groups and Boundaries', Amsterdam.

Waldinger R.

1994 The Making of an Immigrant Niche, „International Migration Review”, nr 28 (1), s. 3-30.

Wimmer A.

2009. Herder's Heritage and the Boundary-Making Approach: Studying Ethnicity in Immigrant Societies, „Sociological Theory”, nr 27 (3), s. 244-270. 